\title{
SECONDARY GEODIVERSITY AND ITS POTENTIAL FOR URBAN GEOTOURISM: A CASE STUDY FROM BRNO CITY, CZECH REPUBLIC
}

\author{
Lucie Kubalíkován ${ }^{1}$, Karel Kirchner ${ }^{1}$, Aleš BajeR ${ }^{2}$ \\ ${ }^{1}$ Institute of Geonics, Academy of Sciences, Brno, Czech Republic. \\ ${ }^{2}$ Department of Geology and Pedology, Faculty of Forestry and Wood Technology, Mendel University in Brno, \\ Czech Republic
}

Manuscript received: April 15, 2017

Revised version: July 01, 2017

\begin{abstract}
KubaLíKOVÁ L., KirChNer K., Bajer A. 2017. Secondary geodiversity and its potential for urban geotourism: a case study from Brno city, Czech Republic. Quaestiones Geographicae 36(3), Bogucki Wydawnictwo Naukowe, Poznań, pp. 63-73. 7 figs, 1 table.

AвSTRACT: Secondary geodiversity (represented by anthropogenic landforms, which can be considered a significant part of geoheritage of certain area) can be seen as an important resource for geotourism and geoeducational activities within urban areas. Brno city (Czech Republic) is rich in these landforms as well as numerous urban areas. Some of them (especially old quarries and underground spaces) are already used for recreation, tourism and leisure or they serve as excursion localities for the university students, some of them are unique from the geoscience point of view and they have also certain added values (historical, archaeological or ecological). However, in some cases, their potential is not fully recognised. The article describes the main anthropogenic landforms within Brno city and analyses their suitability for geotourism and geoeducational activities.
\end{abstract}

KEY wORDS: geosites, geodiversity, anthropogenic landforms, recreation, geoeducation

Corresponding author: Lucie Kubaliková, LucieKubalikova@seznam.cz

\section{Introduction}

Geodiversity, respectively its valuable part geoheritage is undoubtedly the main resource for the geotourism and geoeducational activities (Dowling, Newsome 2010, Dowling 2011). Geodiversity is defined as "the natural range (diversity) of geological (rocks, minerals, fossils), geomorphological (landforms, topography, physical processes), soil and hydrological features. It includes their assemblages, structures, systems and contribution to landscapes" (Gray 2013: 12).
This definition presents the geodiversity as value-free quality of the natural environment; those elements of natural geodiversity that are of significant value to humans for non-depleting purposes, which do not decrease their intrinsic or ecological values are called geoheritage (Sharples 2002). The concept of geoheritage is based on the definition of natural heritage, which was presented already in 1972 (UNESCO 1972). The term geoheritage was defined as those components of natural geodiversity of significant value to humans, including scientific research, education, aesthetics and 
inspiration, cultural development, and a sense of place experienced by communities (Dixon 1996 in Dingwall 2005: 14). A similar definition was presented by Eberhard (1997); he emphasised that geoheritage belongs to the "things we would wish to retain for present and future generations".

In the above mentioned definitions of geoheritage appears the word "natural" (natural geodiversity or primary geodiversity, that means the features formed without the human impact or activity). Obviously, the natural features represent the greatest part of geoheritage (both on global and local scale), but the secondary (or manmade) geodiversity should not be omitted as it also represents a significant resource for tourist and recreation activities (Kubalíková et al. 2016).

Secondary or man-made geodiversity can be defined (analogically to the Gray's definition of geodiversity) as "the range/diversity of the manmade/anthropogenic landforms, including their assemblages, relationships, structures and systems". As well as natural (or primary) geodiversity, the secondary geodiversity has the potential for geotourism and geoeducational activities both outside and within urban areas. There is a lot of examples, where the secondary geodiversity increases overall geodiversity of certain areas (e.g. limestone quarries in the Bohemian Karst). The secondary geodiversity also allows us to know the information which would normally remain hidden and so it helps to understand the evolution of landscape and Earth history, e.g. Klonk near Suchomasty, where the boundary between the Silurian and Devonian period was uncovered thanks to the quarrying and then it was ratified as a Global Boundary Stratotype Section and Point in 1972 (Chlupáč et al. 1972).

In the Czech Republic, the term "secondary geodiversity" was introduced by Cílek (2002) who encompassed its role in the diversity of the landscape in wider meaning. So, specific anthropogenic landforms (which represent particular features and examples of geoheritage) form the full-value and indisputable part of the geoheritage both on global and local level.

If the statements mentioned above are accepted and taken into account, a slightly modified definition of the geoheritage can be presented: components or features of primary (natural) and secondary (man-made or anthropogenic) geodiversity, which are of significant value to humans, including scientific research, education, aesthetics and inspiration, cultural development, and a sense of place experienced by communities.

\section{Secondary geodiversity represented by anthropogenic landforms}

Those components of secondary geodiversity, which form the part of geoheritage, are generally represented by anthropogenic landforms (or manmade landforms). They can be sorted by using various criteria, but for the purposes of this paper, the genetic classification is probably the most suitable. The following classification is based on Kirchner, Smolová (2010) and Szabó et al. (2010):

1) mining landforms (quarries, pits, collapse sinks, subsident depressions, dumps, heaps, shafts, adits etc.),

2) industrial landforms (industrial fields, heaps, underground factories etc.),

3) agricultural landforms (agricultural terraces, piles, ramparts etc.),

4) urban landforms (terraces, ramparts, waste dumps, urban underground, emergency shelters etc.),

5) communication landforms (road or railway cuttings, transport platforms etc.),

6) water system landforms with a subset of littoral landforms (water reservoirs, dams, polders, water canals, mill races, weirs, wells etc.),

7) military landforms (craters, ramparts, fortification systems, underground bunkers etc.),

8) funeral landforms (funeral hills, burial mounds, crypts, tombs, ossuaries etc.),

9) celebration landforms (menhirs, dolmens, cromlechs etc.),

10) other landforms (recreational landforms, archaeological excavations, research landforms etc.).

Probably the most attractive landforms from the geotouristic and geoeducational point of view are the mining landforms (quarries, pits), urban landforms (underground, artificial caves) or communication landforms (road or railway cuttings). However, the analysis of the attractiveness of the specific types of anthropogenic landforms and the validation of the attractiveness of the above mentioned would require detailed research, which should include more anthropogenic features within larger areas and which should use 
the statistic methods and particular assessment of the geoeducational and geotouristic potential.

The secondary geodiversity is also represented by anthropogenic processes and influences on the relief, especially removing large volumes of material and the processes which would not normally exist on certain place: formation of debris cones in quarries, littoral processes on the shores of the artificial lakes etc. The observation and the explanation of these processes can also have interesting geoeducational and geotouristic potential as they help understanding the creation of anthropogenic landforms.

\section{Study area}

The Brno city is the second largest city in the Czech Republic (population: approximately 380,000 inhabitants) and it is situated in the South Moravian Region (southeastern part of the country) (Fig. 1). It lies on the contact of the Bohemian Massif and Carpathian Foredeep, which makes the geology and geomorphology arrangement of the area quite complicated and varied. The following description of the geological and geomorphological settings is based on Novák et al. (1991), Müller, Novák (2000), geological maps and information available on the web page of the Czech Geological Survey (2017a, 2017b) and Demek, Mackovčin (2014).

The Brno Massif (part of Brunovistulicum) and its Paleozoic cover (Moravian-Silesian area)

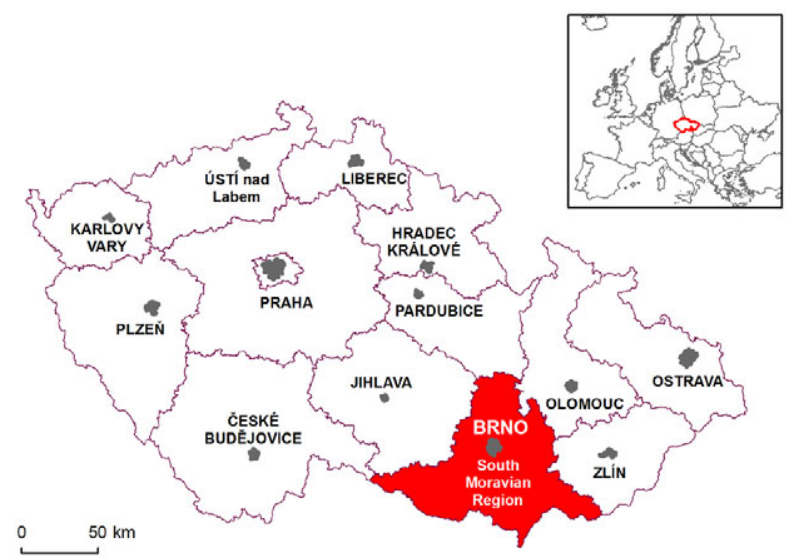

Fig. 1. The position of the study area (Brno city) within the South Moravian region and the Czech Republic.

Source: http://navstevapapeze.cz/_d/mapa_jmk.jpg, accessed 29.06.2017, and modified. forming the basement, is covered by the Neogene sediments of the Carpathian Foredeep. Brno Massif is the Cadomian magmatic body (570-600 Ma old) composed of the Eastern and Western Granodiorite Area, which are separated by the Metabazite Zone composed of slightly metamorphosed basalts with geochemistry similar to basalts of mid-ocean ridges. This is the oldest proved part of the Brno Massif ( 725 Ma old).

The Paleozoic cover is represented by Devonian basal clastic sediments, which crop out in a tectonic slice of the Babí lom zone (e.g. Červený kopec, Žlutý kopec), and Devonian limestones, which can be found especially on the northeastern part of the city (e.g. Hády).

In a few isolated cases in the southeastern part of the study area, the Jurassic limestones occur (e.g. Stránská skála).

The Neogene sediments of the Carpathian Foredeep cover the Brno Massif preferentially along the tectonically predisposed valleys. The Ottnangian gravels prevail in the north part of the city (e.g. Jinačovice trough). The ŘečkoviceKuřim trough (northern part of the study area) is filled by the thick Badenian calcareous clays with sands and gravels at the base, which can be found also in the southern part of the study area under the Quaternary loess and fluvial deposits.

There is currently no active mine or quarry, but the exploitation of construction material (building stone, loess) can be traced back to the $14^{\text {th }}$ century and it has markedly influenced the landscape. The most important limestone quarries are situated on the Northeast of the city (Hády, Lesní lom), diorite was extracted e.g. in the northwestern part of the study area, and the loess and sands were exploited in the southern part of the city.

The study area belongs to two different geomorphological provinces: Czech Highlands (northern and central part of the study area) and Western Carpathians (southern part). In the northern and central part, the relief is tectonically influenced (occurrence of horsts and grabens and tectonically conditioned valleys of Svratka and Svitava) and more pronounced (significant elevations - Petrov, Špilberk, Kraví hora etc.), the southern part is rather flat and it was formed especially during the Neogene and Quaternary. The relief of the study area is strongly influenced by the anthropogenic activity. 


\section{Selected sites}

In this section, some selected geosites and geomorphosites of anthropogenic origin potentially interesting for geotourism and geoeducational activities within Brno city are briefly described (Fig. 2). The list is not exhaustive, and the main criterion for the selection was to identify the sites which would represent the highest number of genetic groups of anthropogenic landforms mentioned above. The information is based on fieldwork, Database of the geological localities (Czech Geological Survey 2017b), Kubalíková et al. (2016) and other resources (cited below).

\section{1 - Hády}

Hády quarry includes three different sites: Hády plain, the upper bench of the limestone quarry and the lower part of the quarry (Růženin lom).
Hády plain has monotone substrate (Vilémovice limestone of Devonian age) rugged by small quarries which can be confused with natural landforms (especially sinkholes). These depressions have been there already since the Middle Ages. They have an important role for the local ecosystems (especially thermophilic vegetation) and they increase the overall biodiversity of the area.

The upper bench of the Hády quarry is important from the stratigraphic and palaeontological point of view. The transgression of the Jura limestones (palaeontologically rich: ammonites, belemnites, crinoids, brachiopods, sporadically teeth of sharks) on the folded Devonian limestones is well visible here (Fig. 3a).

In the lower part of the Hády quarry (Růženin lom), the tectonic thrust of the older rocks of Brno Massif on the younger Upper-Devonian and Lower-Carbon limestones of the Líšeň formation

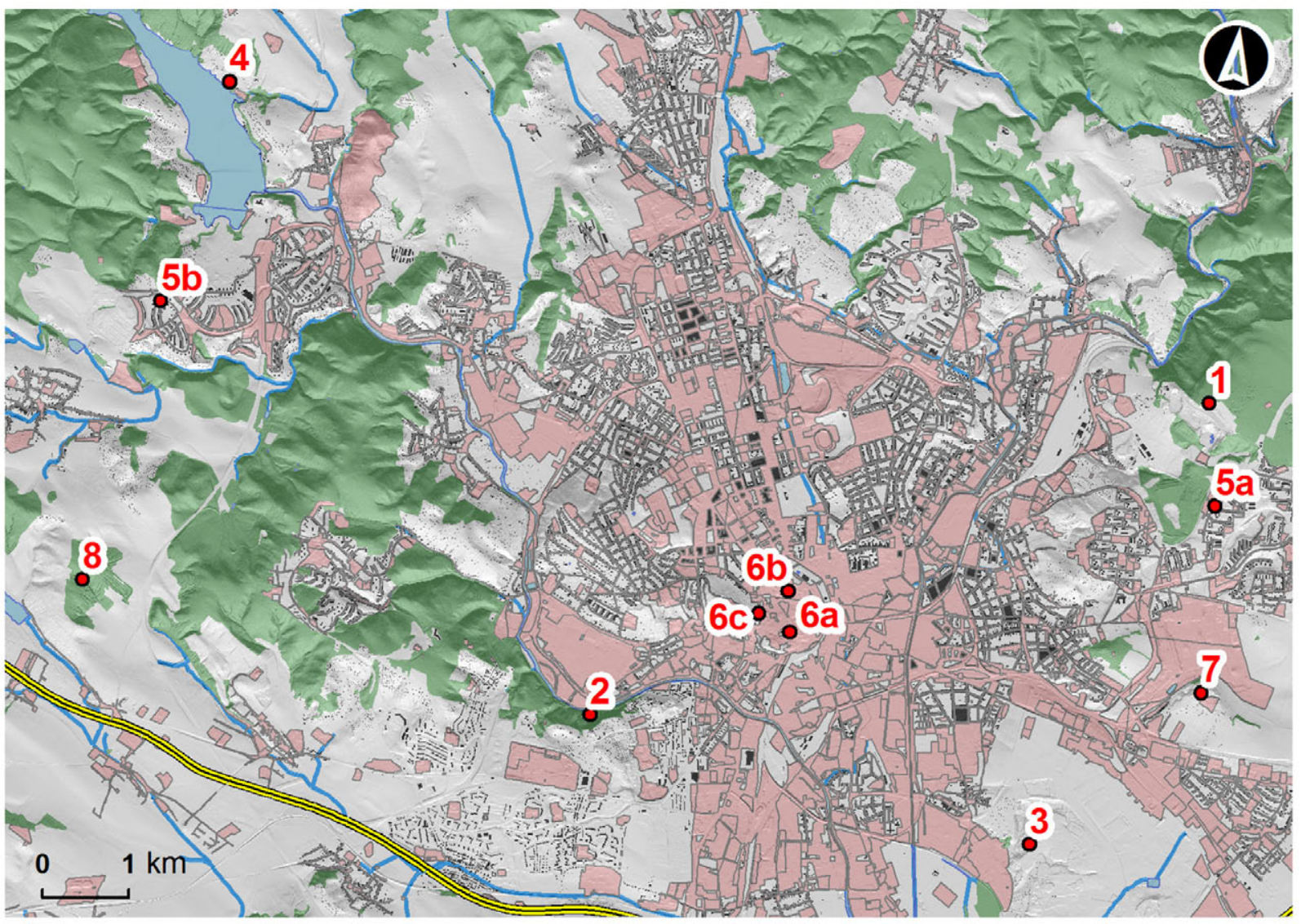

Fig. 2. A sketch of the position of the selected sites within the study area.

1 - Hády, 2 - Červený kopec, 3 - Pískovna Cernovice, 4 - Abrasion cliffs on Brno dam, 5a - Jedovnická Street cutting, $5 b$ - Vejrostova Street cutting, 6a - Labyrinth under Zelný trh, 6b - Ossuary under St. James Church, 6c - Shelter Z-10, 7 - Stránská skála, 8 - Bosonožský hájek.

Source: https:/ / geoportal.gov.cz/web/guest/home, accessed 29.06.2017 and modified. 

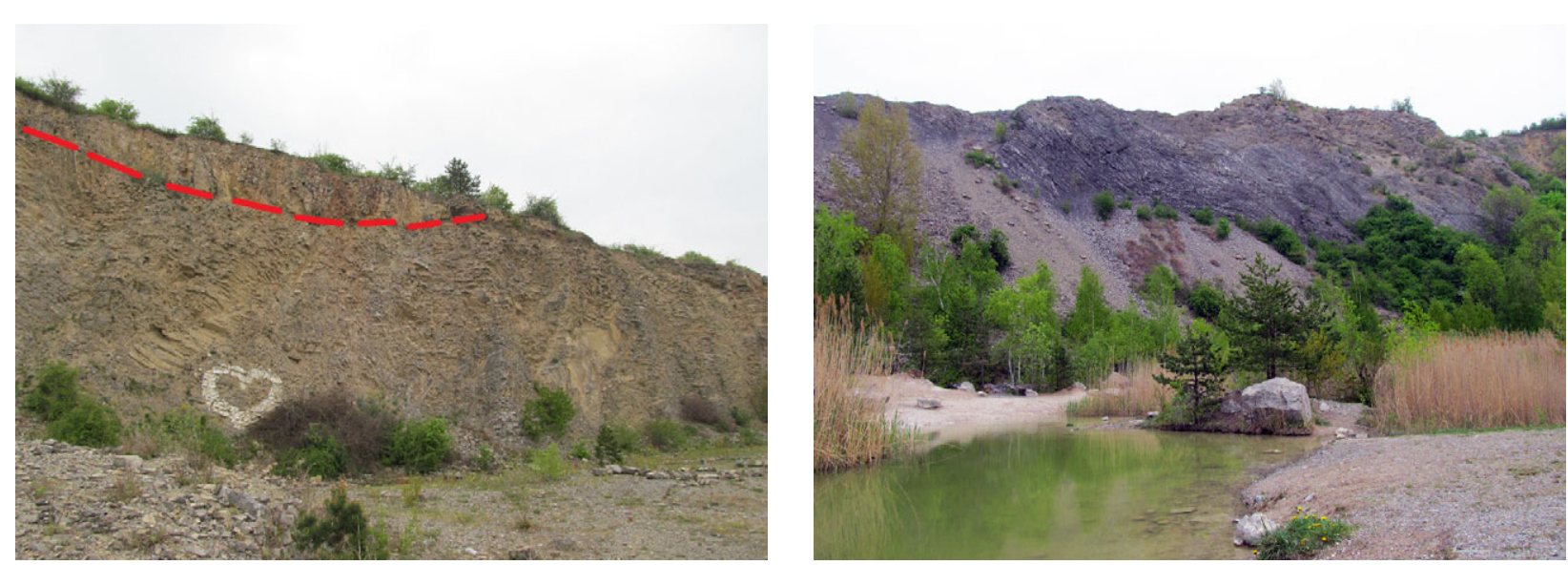

Fig. 3. (a) The transgression of the Jura limestones on the folded Devonian limestones in the upper bench of the Hády quarry, (b) The bottom of the Hády quarry (Ro̊ženin lom) flooded with a lake; in the background, the alternation of limestone, clay limestone and calcic claystone can be observed (Photo: L. Kubalíková, 2015).

can be observed. Also the alternation of limestone, clay limestone and calcic claystone is visible together with other facies that reflect the turbulent sedimentation.

Concerning the anthropogenically conditioned processes, it is possible to observe the formation of debris cones (both in the lower and upper part of the quarry), which has a remarkable geoeducational potential.

The bottom of the quarry is flooded by a lake (Fig. 3b) which is important from the ecological point of view; halophyts and steppe species can be found here.

The site is well accessible, there are several marked paths in the area and an educational trail about the natural features. The site is also widely used as an excursion locality for university students. This complex of anthropogenic landforms is a good example how the overall geodiversity and biodiversity can be increased by the human action and how the anthropogenic landforms can serve the educational and recreational purposes.

Close to this geosite, a new recreational zone is proposed - it should have the character of a park (according to the land-use plan of the Brno city) with possibility of sport activities. At present, the competition of proposals (architectonical-landscape plans) is running. The question is if the park will raise the attractiveness of the geosite.

\section{2 - Červený kopec}

There are two geologically and geomorphologically different localities within Červený kopec. The first one is the system of old small quarries where the Lower-Devonian conglomerate was extracted. The conglomerate has a typical red-violet colour which gave the name to the site (Červený kopec means Red hill) and it presents an illustrative example of the basal clastic sediments and of the sedimentation environment, so it has a high educational value from the lithological and palaeogeographical point of view. The stone was extracted since the Middle Ages and it was widely used as dimension stone; it can be found in the various walls and buildings within Brno (Fig. 4). The second site is a former loess pit (former Kohn's brick-kiln) where the loess profile with fossil soils is preserved. The

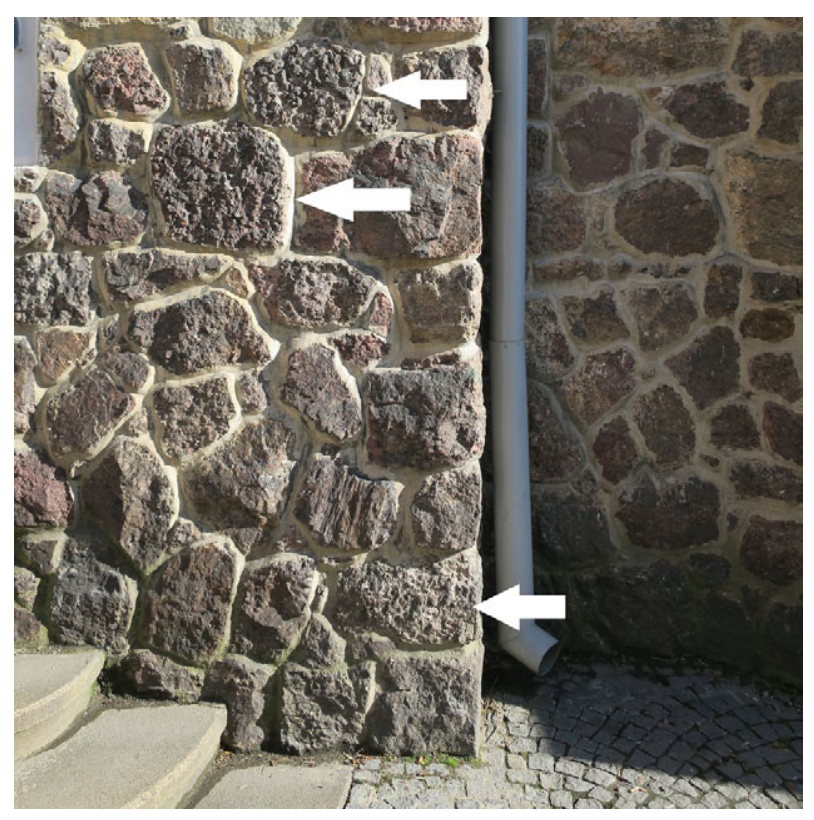

Fig. 4. Old Red conglomerate used as building stone, Biskupská Street (Photo: A. Bajer, 2017). 
site is stratigraphically important and unique in Europe, because it shows the whole Quaternary evolution (approximately $2 \mathrm{Ma}$ ). Thanks to the presence of this complex profile, the site has an immense educational and scientific value (being the topic of a considerable number of scientific papers, e.g. Kukla 1975, Musil 1982, Smolíková 1990, Zeman 1992, Demek et al. 2005). Both sites are well accessible and visible, although the second one partly suffers from vegetation growth.

\section{3 - Pískovna Černovice}

The active sand pit of Černovice is important especially from the stratigraphical and palaeontological point of view. During the extraction of the material, the sediments of Turany terrace were displayed. They lies $40 \mathrm{~m}$ above the present-day level of the Svitava river and they are formed by sand and gravel with pebbles of various provenance. Below this terrace, embedded Brno sands are present. These sands were formed during the LowerBadenian marine transgression and they include concretions of calcareous sandstones or sandy limestones that form the benches, probably the residues of beach sediments. They are also palaeontologically rich (especially shallow water taxons, e.g. Ammonia beccarii). The sediments of the Černovice sand pit represent the deposits of the Outer Carpathian Foredeep. The site has a big educational potential, but it is accessible only with permission after previous consultation of the owner (the land is private and sand extraction is still in progress). Usually, the access for organised groups (e.g. university students) is possible.

\section{4 - Abrasion cliffs on Brno dam}

Brno dam was constructed in the 1930's and it considerably changed the relief of the area. The most remarkable form is the body of the dam itself ( $23.5 \mathrm{~m}$ high, $120 \mathrm{~m}$ long, $7 \mathrm{~m}$ wide), but there are other relevant anthropogenic features. Probably the most interesting and attractive elements are the abrasion cliffs formed thanks to the activity of the waves on the shores caused especially by winds and also by shipping (Šlezingr 1998, 1999 in Peterková 2011). They are developed on the locality of Osada in Quaternary loess sediments and they reach the height of $4 \mathrm{~m}$ (Fig. 5). These landforms are a good example of dynamic geomorphological processes on coastal environments. The cliffs have also an ecological value as they serve as a nest place for various bird species (sand martin, king fisher). The site itself is well known, visible and accessible, the landform is quite illustrative and the ecological feature is also attractive, but the geotourist and educational potential of this site is not fully recognised and used.

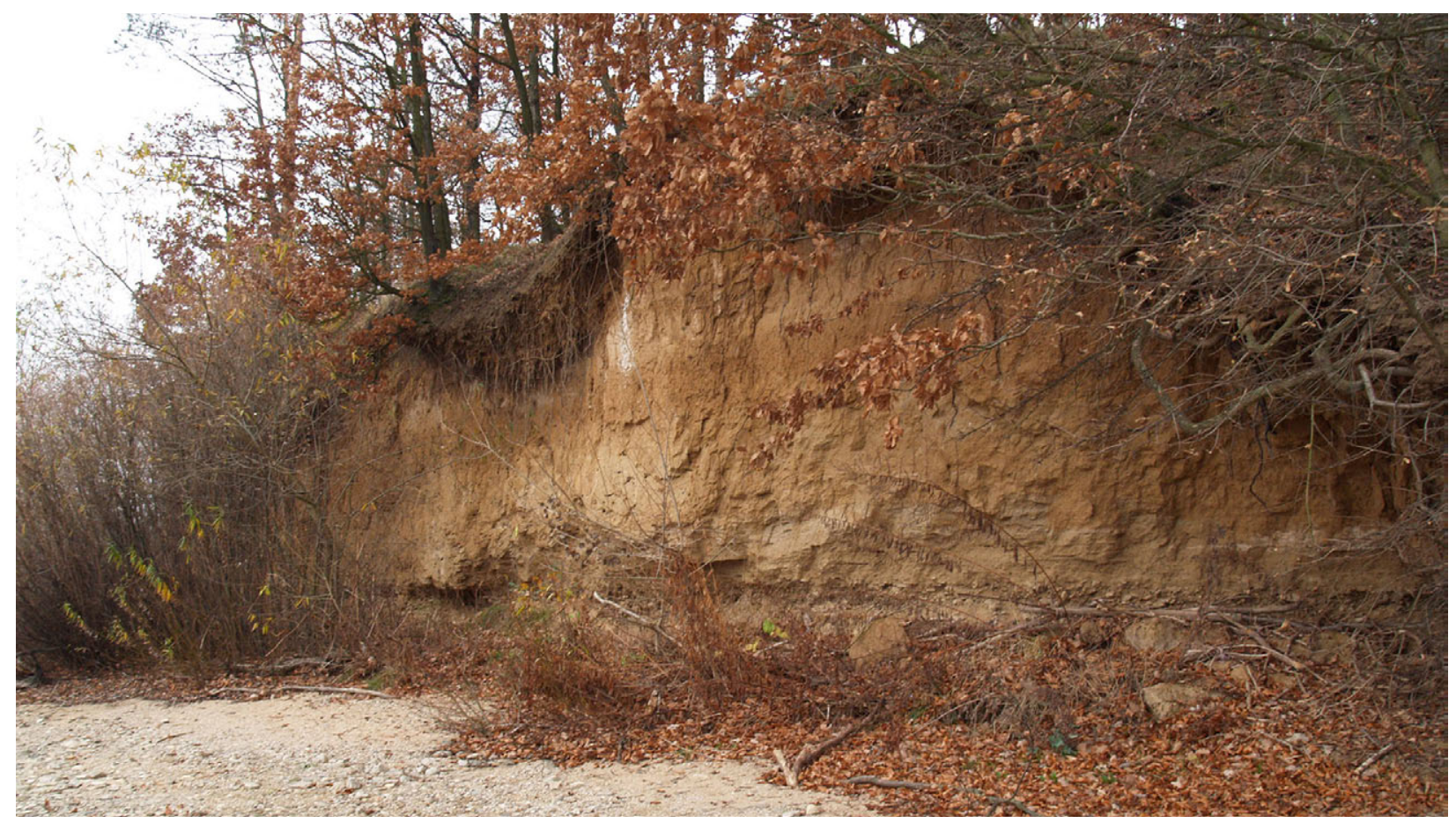

Fig. 5. Abrasion cliff developed in Quaternary loess on the Osada, Brno dam (Photo: K. Kirchner, 2015). 


\section{5 - Jedovnická Street cutting (Líšeň) and Vejrostova Street cutting (Bystrc)}

On Jedovnická Street several rock profiles of Brno Massif's granodiorites (type Královo Pole) are example of road cuttings. The rock profiles are mostly heavily weathered, pinkish to reddish, with brown discolouring due to weathering, medium to coarse-grained biotitic granodiorites. Spectacular ones are up to $2 \mathrm{~cm}$ long, bronze-brown, columnar (pseudohexagonal) biotites. Within the slope debris of this road cutting, the biotite can be very easily found and collected, which has a significant educational potential (Fig. 6).

On the right side of the Bystrc housing estate, on Vejrostova Street, there are visible road cuttings in rocks of Brno Massif's mantle. Differently tectonically affected gneiss, accompanied by younger granodiorites of Brno Massif (type Tetčice) and even younger veins of aplite can be observed here. The profile clearly shows

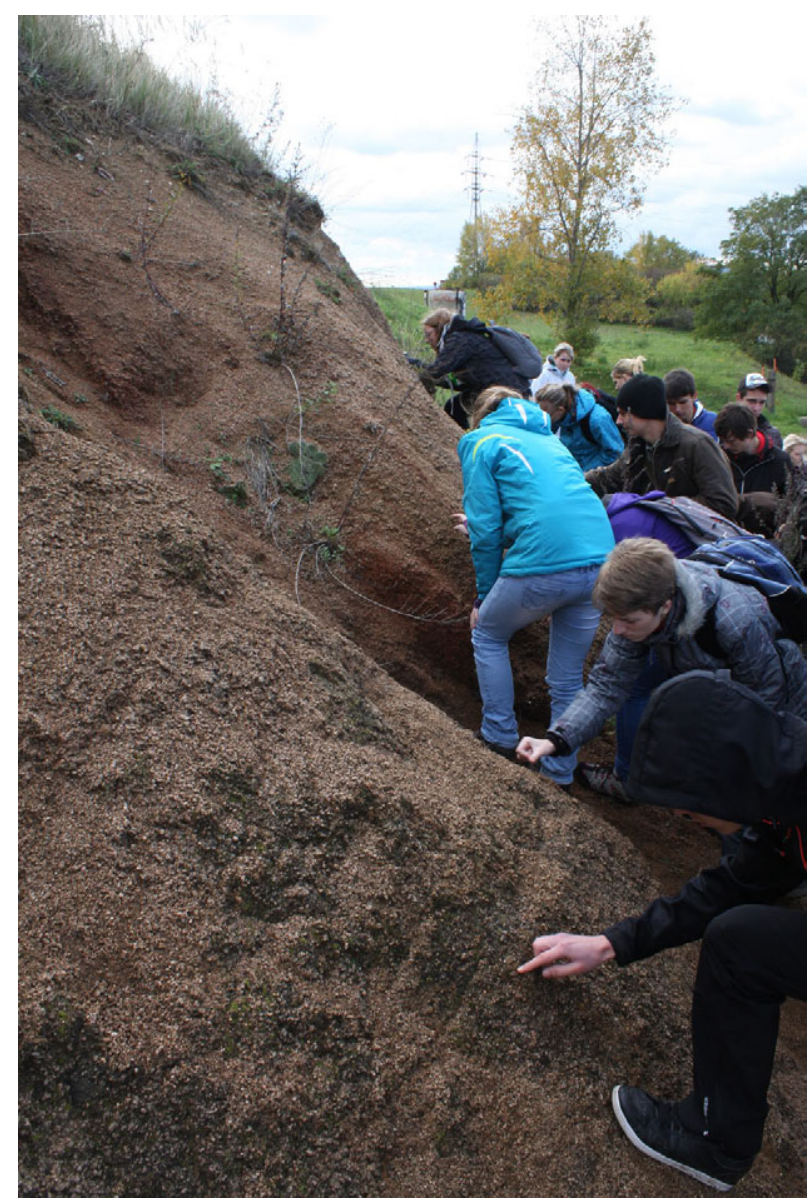

Fig. 6. The communication cutting of Jedovnická street which displays the Brno Massif's granodiorites has a big educational potential (Photo: A. Bajer, 2013). the position of Brno Massif's rocks in the regional context and can serve as field geology textbook.

Both road cuttings are a good example of communication landforms. Generally, the road cuttings have a big educational potential and there is a lot of similar landforms within Brno, however, some of them exist only temporarily and there is often no time to do a description or documentation.

\section{6 - Anthropogenic underground of Brno (Labyrinth, Ossuary, Bunker Z-10)}

The underground spaces underneath Zelný trh (market) have been created since the Middle Ages. The complex of cellars served for food storing, ageing of wine and beer, as war shelters and mainly as a background for the marketers (the markets on the Zelný trh have been held for more than 700 years). In 2009, the cellars and other underground caverns were reconstructed and nowadays they are one of the tourist attractions of the Brno city. From the geoeducational point of view, the Labyrinth underneath Zelný trh is a good example of urban underground with high historical, cultural and archaeological value. The accessibility is good and the site itself is safe (Svoboda 2008).

Another example of anthropogenic underground (or more accurately funeral underground landform) is the Ossuary under the St. James' Church (Fig. 7). The number of buried in the St. James' Ossuary is estimated at 50,000 people, which makes this ossuary the second largest in Europe (after the Parisian catacombs). The anthropological analysis shows that there are buried the victims of the medieval plague and cholera epidemics, and the victims from the Thirty-year war and the Swedish siege of Brno. The underground was opened for public in 2012 and together with Zelný trh underground it is an important tourist site in Brno. From the educational point of view, it represents the significant funeral underground landform with a high anthropological, cultural, historical, archaeological and religious value (Svoboda 2008).

Another interesting underground space is the shelter (or bunker) Z-10. It represents one of the military underground landform within Brno city (there are more shelters, but not all of them are accessible for public). The artificial caverns were excavated in the metarhyolites and metatufs (www. 


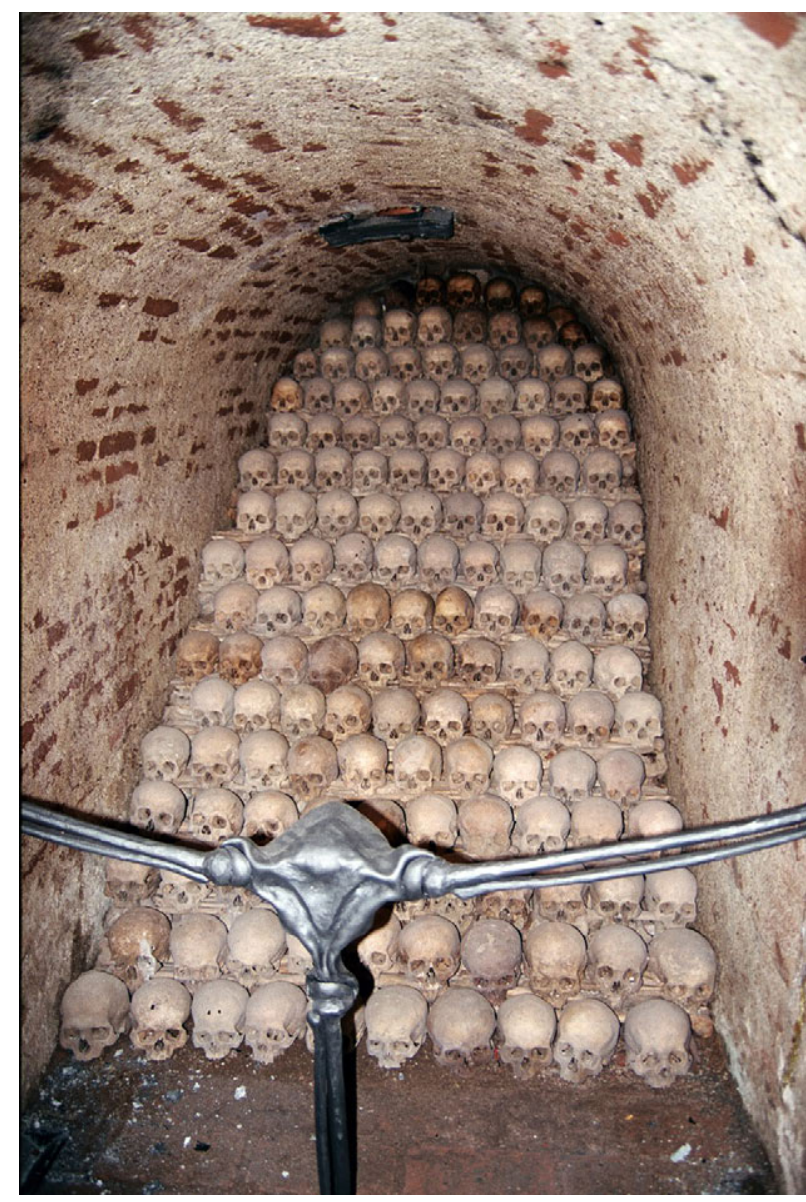

Fig. 7. The Ossuary under the Saint James Church an example of underground funeral anthropogenic landform (Photo: K. Kirchner, 2015).

geology.cz/extranet/mapy, accessed 29.06.2017), which belongs to the oldest rocks within the study area. The purpose of this shelter was to protect prominent people of Brno and South Moravian Region during the Cold War in the case of atomic attack. Originally it served as a war shelter already during World War II. In the 1946-1948 period it was used as a stock for the winery wholesale store Löwy and Šmíd, but after nationalization it was transformed to the shelter with a capacity of 500 people during 3 days. Today, there is a citizens' initiative "American fund" whose aim is to use the originally military landform for cultural purposes. Together with the Tourist Information Centre of Brno it organizes excursions, which are focused mainly on the historical aspects of the site. Unfortunately (as in the case of Brno underground - Ossuary and cellars under Zelný trh), the geological and geomorphological aspects are omitted or only slightly mentioned (Tourist information centre of Brno 2017).

\section{7 - Stránská skála}

Stránská skála is a site of geological, palaeontological, archaeological and historical importance. It is a denudation relict of Jurassic limestones with rich palaeontological findings (e.g. crinoids). The limestone was extracted and used as a decoration stone (e.g. fountain in Špilberk castle in the centre of Brno) and later, before WWII, the site was selected as suitable for the construction of underground shelters and factories.

These underground spaces represent industrial and military landforms within Brno district. For several years, the landforms served as a shelter for homeless people. Today they are closed, but they still attract people. The site is also interesting from the botanical point of view (Pulsatilla) and it is abundantly visited during the spring. Archaeologically it is an important Palaeolithic locality that shows evidence of settlement already 600,000 year BP (Homo erectus). It is one of the most important locality from this point of view. Later, the evidence of human presence is proved in the period 30,000 - 40,000 year BP.

The site is also important from the palaeogeographical point of view: the Svitava river flew nearby (today, the position of the stream channel is different) and created numerous branches here, so the landscape had a different pattern compared to today.

The limestone quarry is used as an excursion locality and generally it is a favourite place for visits and walks, the accessibility by public transport is good. The marked tourist paths are present as well as tourist shelters, the site has thus a big potential for geoeducation and geotourism too.

\section{8 - Bosonožský hájek}

Bosonožský hájek is located westward of Brno in the eastern slopes of the Bobravská vrchovina Highland (1.1 km southeast from city district Brno Žebětín). It is a unique example of intensive gullying of Pleistocene loess deposits; locally the incision reached even the underlying granitoid bedrock. Three types of gully networks can be recognised according to their extension and morphology. The approximate length of whole network is about $18,354 \mathrm{~m}$ and the density is about $39.25 \mathrm{~km} \cdot \mathrm{km}^{-2}$ (Kirchner et al. 2011).

The formation and development of a gully network is conditioned by natural factors and human activities, e.g. intensive water 
erosion during flash floods or track construction (Kirchner et al. 2011). In the southern part of the study area, there are remnants of historical agricultural terraces (terraces were used probably as vineyards) dissected by erosion. In the eastern part of this site, historical paths pass through the study area (this fact is documented by historical maps from the $2^{\text {nd }}$ Military Survey of 1836-1852). These paths were eroded and deep gullies were formed and they are still well visible. This territory is a subject of interdisciplinary research with respect to dating of the main phases of natural and human-induced gully incision.

\section{Analysis of the geotourism and geoeducational potential}

Based on the terrain research, freely accessible maps (Národní geoportál INSPIRE, https:/ / geoportal.gov.cz/web/guest/home, accessed 29.06.2017) and other resources (cited above), a SWOT analysis of the geotourism and geoeducational potential of the sites was done (Table 1). SWOT analysis is a simple assessment tool, which presents Strengths, Weaknesses, Opportunities and Threats. It helps with strategic planning and decision-making and it is widely used both for planning in companies and planning the community or regional development.

Based on the SWOT analysis it can be said that anthropogenic landforms within Brno possess a potential for geotourism and geoeducational activities, but in some cases the potential is not recognised. The next step of the research is the detailed analysis and evaluation of the geotourism and geoeducational purposes of particular sites based on methods used within the concept of geomorphosites (e.g., Coratza, Giusti 2005, Pralong 2005, Reynard et al. 2007, Pereira, Pereira 2010, Kubalíková 2013, Bajer et al. 2015, Kubalíková, Kirchner 2016) and eventually, analysis of the demand of potential visitors. Then, the specific proposals for the geoeducational and geotouristic use will be presented.

\section{Conclusions}

Although some anthropogenic landforms represent big intervention to the natural ambient, some of them can increase the diversity of natural environment and they can create good basis for diversification of the ecosystems. Also, some of anthropogenic landforms are very important from the historical and archaeological point of view, so the overall value of these geosites and geomorphosites is composed of the scientific and cultural value. Moreover, some landforms uncover the features, which would normally remain hidden; in this sense they increase the geodiversity of the area. As they show various geological outcrops or geomorphological processes, they can serve as a terrain handbook for

Table 1. SWOT analysis of the geotourist and geoeducational potential of the anthropogenic landforms within Brno city.

\begin{tabular}{|c|c|}
\hline & Weaknesses \\
\hline $\begin{array}{l}\text { - big diversity (although there are no menhirs or cromlech } \\
\text { (celebration landforms in general), but the rest of the genetic } \\
\text { groups is represented) } \\
\text { - high number of sites } \\
\text { - representativeness and easy recognizability of the landforms } \\
\text { and processes (pedagogical and educational potential) } \\
\text { - accessibility (on foot, by public transport) } \\
\text { - existence of tourist paths }\end{array}$ & $\begin{array}{l}\text { - some sites and areas are private, accessibility is } \\
\text { restricted or possible only with a permission } \\
\text { - the geo-feature is oppressed (esp. Brno under- } \\
\text { ground) and consequently, the interpretation and } \\
\text { promotion of the geo-features of some sites is not } \\
\text { good } \\
\text { - inadequate use of some sites (waste, vandalism, } \\
\text { high exposure to the visitors) }\end{array}$ \\
\hline Opportunities & \\
\hline $\begin{array}{l}\text { - higher promotion of the geo-features can increase the attrac- } \\
\text { tiveness of the sites } \\
\text { - the added values of the sites can attract visitors to the } \\
\text { geo-features } \\
\text { - geoeducation, sustainable geotourism and recreation as an } \\
\text { alternative for "classical" trips to the Brno surroundings } \\
\text { (e.g. Moravian Karst which is overloaded by visitors) } \\
\text { - recognizing the importance of geo-features }\end{array}$ & $\begin{array}{l}\text { - not politically attractive theme } \\
\text { - ongoing and continuing inadequate use of some } \\
\text { sites } \\
\text { - high exposition to the visitors, damage of the } \\
\text { sites } \\
\text { - no conception of the geoeducation and geotour- } \\
\text { ism on the urban level (or regional level) } \\
\text { - the fight between the geoscientists and biologists }\end{array}$ \\
\hline
\end{tabular}


Earth sciences and they can be used for geoeducational purposes. Anthropogenic landforms are often visually attractive; so they have big potential for recreational and tourist activities. In many cases, anthropogenic landforms also document prehistoric and historical development of relief and landscapes and therefore they are a part of the geomorphological attempt to geodiversity (Thomas 2012).

Thus, secondary geodiversity with its particular features - anthropogenic landforms undoubtedly represents a significant part of the Brno city's geoheritage and it can be viewed as a considerable resource for geotourism and geoeducational activities. In some cases, its potential is already recognised and rationally used, but other important sites are neglected, poorly promoted and the care about them is not sufficient. However, there are some important projects on geodiversity, geotourism and geoeducation within Brno and South Moravian Region:

- Geological walks (Bajer 2012),

- Geology of the Brno and its surroundings (Müller, Novák 2000),

- Database of the geological localities (Czech Geological Survey 2017b),

- Significant geological sites of Moravia and Silesia (Vávra, Štelcl 2014),

- Some non-profit organisations hold programs for children, guided excursions, talks and presentations.

These projects are a good starting point for similar activities and more detailed analysis of the potential of secondary geodiversity in the study area.

Conceptually, there is no document about geoeducation and geotourism for Brno and its surroundings or for the South Moravian Region; in the Conception of the environmental education for the South Moravian Region (Jihomoravský kraj 2010), unfortunately, there is nothing about geodiversity. At the State level, general documents on geodiversity, geoeducation and geotourism are missing too.

Above-mentioned facts should be respected and included into the landscape management, regional planning and development strategies. The cooperation of the specialists of the different branches is also desirable (scientists, teachers in the primary, secondary and high schools, local authorities, owners of the landforms), otherwise the geoeducational and geotouristic potential of these significant sites will not be fully and rationally exploited.

\section{Acknowledgement}

The article was supported by long-term conceptual development support of research organisation (Institute of Geonics, Czech Academy of Sciences, v.v.i.) RVO: 68145535.

\section{References}

Bajer A., 2012. Geologické vycházky okolím Brna (Geological walks around Brno). Rezekvítek Brno.

Bajer A., Kirchner K., Kubalíková L., 2015. Geodiversity values as a basis for geosite and geomorphosite assessment: a case study from Žd'árské Vrchy Highland. In: Lněnička L. (ed.), Proceedings of 23rd Central European Conference: 56-69.

Chlupáč I., Jaeger H., Zikmundová J., 1972. The Silurian-Devonian boundary in the Barrandian, Bulletin of Canadian Petroleum Geology 20(1): 104-174.

Cílek V., 2002. Geodiverzita - opomíjený aspekt ochrany př́rody a krajiny (Geodiversity - a neglected aspect of nature and landscape conservation). Zpráoy o geologických výzkumech v roce 2001: 13-15.

Coratza P., Giusti C., 2005. Methodological proposal for the assessment of the scientific quality of geomorphosites. Il Quaternario, Italian Journal of Quaternary Sciences 18(1): 305-313.

Czech Geological Survey, 2017a. Maps. Online: www.geology.cz/extranet/mapy (accessed 30 March 2017).

Czech Geological Survey, 2017b. Significant geological localities of the Czech Republic. Online: lokality.geology.cz (accessed 30 March 2017).

Demek J., Havlíček M., Kirchner K., Nehyba S., Lisá L., 2005. K rozšíření poznatků o kvartérních sedimentech na Červeném kopci v Brně (Distribution of Quaternary sediments on the Červený kopec (Red Hill) in Brno). In: Geomorfologický sborník. České Budějovice: Jihočeská univerzita v Českých Budějovicích, 2005: 159-163.

Demek J., Mackovčin P. (eds), 2014. Zeměpisný lexikon ČR. Hory a níziny (Geographical lexicon. Mountains and lowlands). Agentura ochrany přírody a krajiny ČR, Brno, 607 p.

Dingwall P., 2005. Geological world heritage: a global framework. A Contribution to the Global Theme Study of World Heritage Natural Sites. IUCN, WCPA, UNESCO.

Dixon G., 1996. Geoconservation: An International Review and Strategy for Tasmania. Occasional Paper 35, Parks \& Wildlife Service, Tasmania, $101 \mathrm{p}$.

Dowling R.K., 2011. Geotourism's Global Growth. Geoheritage 3(1): 1-13.

Dowling R.K., Newsome D. (eds), 2010. Geotourism. The tourism of geology and landscape. Goodfellow Publishers, Oxford, $246 \mathrm{p}$.

Eberhard R. (ed.), 1997. Pattern and Process: Towards a Regional Approach to National Estate Assessment of Geodiversity. Technical Series No. 2, Australian Heritage Commission 
and Environment Forest Taskforce, Environment Australia, Canberra.

Gray M., 2013. Geodiversity: Valuing and Conserving Abiotic Nature. Wiley Blackwell, Chichester, 495 p.

Jihomoravský kraj, 2010. Koncepce EVVO Jihomoravského kraje na obdobi 2011-2020 (Conception of the environmental education for the South Moravian Region). JMK, Brno. Online: https://www.kr-jihomoravsky.cz/Default.aspx?ID=154180\&TypeID=2 (accessed 29 June 2017).

Kirchner K., Münster P., Máčka Z., 2011. Stržový systém v Bosonožském hájku - jedinečný geomorfologický fenomén západně od Brna (Gully system in Bosonožský hájek - a unique geomorphological phenomenon west of Brno). Geologické výzkumy na Moravě a Slezsku 18(2): 33-36.

Kirchner K., Smolová I., 2010. Základy antropogenní geomorfologie (Elements of anthropogenic geomorphology). Univerzita Palackého v Olomouci, $287 \mathrm{p}$.

Kubalíková L., 2013. Geomorphosite assessment for geotourism purposes. Czech Journal of Tourism 2(2): 80-104.

Kubalíková L., Bajer A., Kirchner K., 2016. Secondary geodiversity and its potential for geoeducation and geotourism: a case study from Brno city. In: Fialová J., Pernicová D. (eds), Public recreation and landscape protection - with nature hand in hand... Conference proceeding. Mendel University Brno: 224-231.

Kubalíková L., Kirchner K., 2016. Geosite and Geomorphosite Assesment as a Tool for Geoconservation and Geotourism Purposes: a Case study from Vizovická vrchovina Highland (Eastern Part of the Czech Republic). Geoheritage 8(8): 5-14.

Kukla G., 1975. Loess stratigraphy of central Europe. In: Butzer K.W., Isaac G.L. (eds),

After the Australopithecines, Mouton Publishers: 99-188.

Müller P., Novák Z., 2000. Geologie Brna a okolí (Geology of Brno and its surroundings). Ceský geologický ústav Praha, $90 \mathrm{p}$.

Musil R., 1982. Současný stav poznatků o kvartéru Brněnské kotliny (The current state of knowledge about the Quaternary of the Brno basin). Studia Geographica 80: 261-268.

Národní geoportál INSPIRE, 2017. Maps. Online: geoportal. gov.cz/web/guest/home (accessed 26 June 2017).

Novák Z. et al., 1991. Geologická mapa 1:50 000, list 24-32 Brno (Geological map 1:50 000, sheet 24-32 Brno). Český geologický ústav, Praha.

Pereira P., Pereira D., 2010. Methodological guidelines for geomorphosite assessment. Géomorphologie: relief, processus, environnement 3: 215-222.
Peterková L., 2011. Reliéf a geomorfologický vývoj řeky Svratky v brněnském prostoru v severozápadní části Bobravské vysočiny (Relief and geomorphological development of the Svratka river in Brno area in NW part of Bobravská vrchovina highland). Ph.D. thesis. Masarykova univerzita, Př́rodovědecká fakulta, Brno, $147 \mathrm{p}$.

Pralong J.P., 2005. A method for assessing tourist potential and use of geomorphological sites. Géomorphologie: relief, processus, environnement 3: 189-196.

Reynard E., Fontana G., Kozlik L., Scapoza C., 2007. A method for assessing the scientific and additional values of geomorphosites. Geographica Helvetica 62(3): 148-158.

Sharples C., 2002. Concepts and principles of geoconservation. Tasmanian Parks \& Wildlife Service website, September 2002. Online: xbiblio.ecologia.edu.mx/biblioteca/ Cursos/Manejo/Geoconservation.pdf (accessed 9 March 2011).

Šlezingr M., 1998. Vliv lodní dopravy na Brněnské přehradě na vznik abraze břehů (Influence of shipping on the Brno Dam to the creation of shoreline abrasion). In: Přehradné dni 1998 - sborník referátov, Košice: 154.

Šlezingr M., 1999. Prezentace výsledků monitoringu postupu abraze na březích údolní nádrže Brno v letech 1989 1999 (Presentation of the results of the monitoring of the process of abrasion on the banks of the Brno reservoir in the years 1989-1999). Vodní hospodárství 9: 192-193.

Smolíková L., 1990. Regionální paleopedologie (Regional Palaeopedology). In: Němeček J., Smolíková L., Kutílek M., 1990. Pedologie a paleopedologie, Academia: 405-479.

Svoboda A., 2008. Brněnské podzemí I (Brno underground I). R-ateliér spol. s r.o., Brno, 168 p.

Szabó J., Dávid L., Loczy D. (eds), 2010. Anthropogenic Geomorphology. A Guide to Man-Made Landforms. Springer, Dordrecht, $250 \mathrm{p}$.

Thomas M.F., 2012. A geomorphological approach to geodiversity - its applications to geoconservation and geotourism. Quaestions Geographicae 31(1): 81-89.

Tourist information centre of Brno, 2017. Shelter 10-Z. Online: ticbrno.cz/cs/podzemi/kryt-10-z (accessed 30 March 2017).

UNESCO, 1972. Convention concerning the protection of the world cultural and natural heritage. Online: whc.unesco. org/archive/convention-en.pdf (accessed 17 November 2010).

Vávra V., Štelcl J., 2014. Významné geologické lokality Moravy a Slezska (Significant geological localities of Moravia and Silesia). Masarykova Univerzita Brno, 290 p.

Zeman A., 1992. New data on the Quaternary at Červený kopec hill in Brno. Scripta Geology 22: 123-131. 